\title{
O NOVO CÓDIGO DE PROCESSO CIVIL E O DIREITO DE FAMÍLIA
}

\author{
André Luis Rodrigues Pedrozo ${ }^{1}$
}

\section{INTRODUÇÃO}

Recentemente foi sancionada a Lei n. 13.105/15, que é o texto do novo Código de Processo Civil. O legislador pátrio alterou substancialmente a forma da solução dos conflitos no que se refere aos processos que tratam da relação familiar.

É incontroverso que a família vem sofrendo modificações profundas ao longo do tempo, criando-se novos paradigmas até então jamais pensados na sociedade extremamente machista e patriarcal do passado. Os novos arranjos familiares estão em voga nas relações familistas, tornando-as mais humanizadas. Foi-se o tempo em que a consanguinidade prevalecia sobre o afeto. Hoje em dia, não raras vezes, o afeto prepondera sobre os laços de sangue, fortalecendo a parêmia: "pai é quem cria”.

Outrossim, tivemos a questão dos direitos assegurados aos casais homoafetivos, que há tempos aguardavam um posicionamento do Poder Judiciário. Enfim, todas essas transformações sociológicas que ocorreram ao longo dos anos, como não poderia deixar ser, também refletiram-se no estatuto processual que, ao tratar das relações familiares, não tinha um diligente cuidado.

Ao discorrer sofre as transformações da família, Carlos Silveira Noronha, em percuciente reflexão, afirma:

1 Advogado militante, especialista em Direito Civil e Processo Civil, aluno especial na Pós-Graduação stricto sensu na Faculdade de Direito da UFRGS, na área de direito de família e sucessões. 
Durante o longo estágio temporal transcorrido entre os sistemas antigos e a modernidade das instituições em geral, a família vem sendo alvo de profundas transformações. Embora ainda se verifique em algumas sociedades políticas a conservação da família patriarcal, é certo que os primitivos modelos pré-romano e romano-clássico, constituídos em torno da autoridade absoluta do primitivo chefe do clã, da tribo e mesmo a do pater familias, não merecem mais a contemplação do direito moderno. ${ }^{2}$

Hoje em dia, em se tratando de disputas no seio familiar, é indiscutível que levam a uma série de desgastes emocionais, causando sofrimento aos partícipes da contenda. Fundada no anseio de diminuir a beligerância das partes, a nova lei inaugurou um capítulo especial que alude às ações de família.

Embora todos os temas do direito de família sejam palpitantes na nova legislação a merecer reflexões, optamos pela linha intelectiva da notável inovação do novo Código de Processo Civil, que são os processos contenciosos de família previstos nos artigos 693 e seguintes.

A despeito da existência de legislação esparsa, já urgia há tempo ope legis disposições processuais que dis- corressem sobre a disciplina familiar mais preocupada com o ser holístico.

Por isso, consideramos que as modificações oriundas da sistemática procedimental no novo Código de Processo Civil chegaram em conveniente momento histórico.

Por primeiro, faremos um pequeno introito das modificações que a nova legislação trouxe a ordem jurídica processual.

Ao depois, iremos irromper mais detidamente a normatização do processo familista contencioso no novo Código de Processo Civil, analisando artigo por artigo, trazendo ao leitor elucubrações sobre a quaestio.

Começaremos inquirindo o novo artigo 693 do novo Codex, que lista quais são as ações judiciais açambarcadas aos processos contenciosos de família. Ponderaremos se o rol é taxativo ou exemplificativo.

Continuaremos a protair o conhecimento da novel legislação, ao apreciar 0 artigo 694, que suscita uma nova visão dos processos de família, introduzindo a mediação e a conciliação.

Por sua vez, o artigo 695 da nova lei Adjetiva assevera qual será o procedimento desde o recebimento da petição inicial até a designação da audiência de mediação e conciliação, tecendo algumas críticas ao artigo de lei.

2 NORONHA. Carlos Silveira. A função social do Direito de Família na tutela dos entes familiares. In: NORONHA. Carlos Silveira (organizador). As novas posturas jurídicas em prol da família a partir da codificação civil de 2002. Porto Alegre: Editora Sulina, 2013. p. 28-29. 
Comentaremos, também, o previsto no artigo 696, no qual o legislador demonstrou todo o esforço na resolução do conflito ao dividir em quantas audiências forem necessárias para que as partes alcancem o desfecho da divergência.

Embora todo o estímulo para o término do litígio, não pode o processo durar ad eternum, sob pena de infringir preceito constitucional da razoável duração do processo. ${ }^{3}$ Portanto, se as partes não chegarem a um acordo, o processo tomará o rumo do procedimento comum, à luz do artigo 697 do novo Código de Processo Civil.

Outra novidade que apreciaremos é o novo papel no Ministério Público vaticinado no artigo 698 do novo Código de Processo Civil.

Por fim, analisaremos o artigo 699 que trata das relações nas quais há abusividade ou alienação parental, sobrelevando qual deve ser a postura do judiciário em tais casos.

\section{DIREITO DE FAMÍLIA NO NOVO CÓDIGO DE PROCESSO CIVIL}

Uma das grandes novidades no novo Código de Processo Civil foi introduzida no Capítulo X, Título III, Parte Especial, que trata dos procedimentos ${ }^{4}$ especiais, nos quais foi concebida uma atuação própria para as ações de família contenciosas.

Os procedimentos especiais contêm atos adequados, segundo o critério do legislador, a certas situações peculiares que são trazidas a juízo: têm cabimento nas hipóteses expressamente previstas nas normas que os disciplinam. ${ }^{5}$

3 Art. 5: Todos são iguais perante a lei, sem distinção de qualquer natureza, garantindo-se aos brasileiros e aos estrangeiros residentes no País a inviolabilidade do direito à vida, à liberdade, à igualdade, à segurança e à propriedade, nos termos seguintes: [...] LXXVIII - a todos, no âmbito judicial e administrativo, são assegurados a razoável duração do processo e os meios que garantam a celeridade de sua tramitação.

4 Enquanto processo é o conjunto dos atos legais necessários pra que seja solucionada a lide, instrumento por meio do qual se opera a jurisdição; o procedimento é, junto com a participação ativa das partes ma instrução do processo, o aspecto puramente formal e exterior deste, o meio extrínseco de sua instauração, desenvolvimento e extinção. LUCENA, João Paulo; DA SILVA, Ovídio A. Baptista. Comentários ao código de processo civil: dos procedimentos especiais. Arts.1.103 a 1.210. São Paulo: Editora Revista dos Tribunais, 2000. p. 63.

5 CINTRA, Antonio Carlos de Araújo; GRINOVER. Ada Pellegrini; DINAMARCO. Cândido Rangel. Teoria geral do processo. 29. ed. São Paulo: Editora Malheiros, 2013. p. 366. 
Tendo as suas próprias especificidades que o diferenciam dos demais procedimentos, os especiais apresentam características marcantes, quer por influência do direito material controvertido que se procura fazer valer por meio do processo, quer pelo próprio regrame processual que são submetidos. ${ }^{6}$

Até então, não existia no Código de Processo Civil de 1973 qualquer provisionamento quanto a algum procedimento específico nas ações que tratam de temas tão sensíveis, que estão a merecer um zelo especial, visto que cuidam de relações afetivas no seio familiar.

O novo Código de Processo Civil nos brindou, em boa hora, com um procedimento peculiar às questões judiciais familiares que merecem uma proteção especial, face às características do processo.

A nova legislação trouxe à ordem jurídica algumas especificidades, que visam maior êxito na mediação e conciliação de conflitos familiares.

Neste sentido Fernanda Tartuce:
O novo CPC reconhece a importância social das lides familiares e destaca um capítulo para abordá-las; trata-se de uma iniciativa pioneira, especialmente considerando a omissão dos Códigos anteriores em termos de sistematização da matéria."7

Trata-se de novidade no Código de Processo Civil brasileiro. A ideia é bem vinda, pois responde a uma necessidade. Comumente afirma-se que, quando se trata de lide de direito de família, o processo assume certas peculiaridades como decorrência da necessidade de adaptação, sendo a preferência pela solução consensual uma dessas caraterísticas. ${ }^{8}$

Portanto, não há uma inovação no sistema processual familista.

\section{DO CONTENCIOSO FAMILISTA}

\subsection{Das ações e pretensões}

A normatização das ações de família no novo Código de Processo Civil se inicia no artigo 693, que aduz:

6 MARCATO. Antônio Carlos. Procedimentos Especiais. 14. ed. São Paulo: Editora Atlas, 2010. p. 57.

7 TARTUCE. Fernanda. Possibilidade de diversas sessões consensuais no juízo familiar. Revista do Instituto Brasileiro de Direito de Família. 19. ed., fev./mar. 2015, p. 10. 8 WAMBIER, Teresa Arruda Alvim (coord.). Primeiros comentários ao novo código de processo civil: artigo por artigo. 1. ed. São Paulo: Editora Revista dos Tribunais, 2015. p. 1.028 . 
Art. 693. As normas deste Capítulo aplicam-se aos processos contenciosos de divórcio, separação, reconhecimento e extinção de união estável, guarda, visitação e filiação.

Parágrafo único. A ação de alimentos e que versar sobre interesse de criança ou adolescente observarão o procedimento previsto em legislação específica, aplicando-se, no que couber, as disposições deste Capítulo.”

A primeira percepção é a de que se trata de norma aplicável à Jurisdição contenciosa. Outra indagação é saber se o rol do artigo 693, caput, é mera- mente exemplificativo (numerus apertus) ou taxativo (numurus clausus).

Evidentemente, por ser uma legislação novíssima, com o passar do tempo tanto a construção doutrinária quanto a jurisprudencial irão dar uma resposta efetiva a inquietação.

Por ora, pensamos que a abrangência das normas se limita às ações de divórcio, separação ${ }^{9}$, reconhecimento e extinção de união estável, guarda, visita e filiação, quedando-se as questões dos alimentos que continuam reguladas por legislação especial.

9 Com o intuito de trazer ao debate, faremos uma pequena digressão quanto ao controvertido instituto jurídico da separação (em todas as suas modalidades). Existe uma acalorada discussão doutrinária que questiona, após a Emenda Constitucional número 66 de 2010, se houve ou não a extinção do termo "separação judicial e extrajudicial". Juristas se dividem quanto ao tema. A festejada autora Regina Beatriz Tavares da Silva (In: Divórcio e Separação após a EC n. 66/2010. 2. ed. São Paulo: Editora Saraiva, 2012) afirma que "a EC/2010 não extinguiu a separação judicial e extrajudicial"; por sua vez, Paulo Lôbo tem posicionamento diverso. Diz o autor: "O novo CPC não regulamenta a separação judicial, nem poderia fazê-lo, pois a Emenda Constitucional n. 66/2010 a suprimiu, e revogou, por incompatibilidade, todos os dispositivos do Código Civil que a regulamentavam. Tampouco poderia a lei determinar a continuidade de normas anteriores revogadas, pois isso caracteriza repristinação, inadmissível no Direito brasileiro. Em suma, a separação judicial não foi repristinada pelo novo CPC e ficou prevista apenas a homologação judicial de separação convencional dos cônjuges, se assim fizerem, mas que não apresenta qualquer utilidade para a dissolução do casamento, pois o divórcio (extrajudicial ou judicial) não depende dela, ou seja, não é antecedida por ela. Tampouco pode ser convertida em divórcio. Daí sua completa inutilidade”. (In: Revista do Instituto Brasileiro de Família, 19. ed. fev./mar. 2015.) Pensamos que não houve a supressão da separação no ordenamento, porquanto se trata de um instituto autônomo, independente da coexistência de outro. Ao depois, a nova legislação previu em inúmeros artigos a possibilidade de, ainda, ser possível fazer uso da separação antes do divórcio. Quisesse o legislador dizer que o instituto estava extinto, seria uma oportunidade de eliminá-lo na legislação projetada. Contudo, houve a manutenção em inúmeros artigos, ad exemplum: art. 23, inciso III; art. 53, inciso I; art. 189, inciso II; art. 693; art. 732; art. 733. Todos estes dispositivos tratam da separação judicial e reconhecem sua existência. 
As regras previstas entre os arts. 693 a 699 do CPC aplicam-se somente de forma subsidiária às ações de alimentos e às de interesse de criança ou adolescente. Para estas causas, incide com preferência o contido na Lei 5.478, de 1968 (Lei de Alimentos), com as modificações introduzidas pelo CPC (art. 1.072), e a Lei 8.069, de1990 (Estatuto da Criança e do Adolescente). Assim, as questões de filiação que envolva interesse de criança ou adolescente (a exemplo da adoção) aplicarão, antes, os preceitos do Estatuto da Criança e do Adolescente e apenas supletivamente o contido nos arts. 693 a 699 do CPC. ${ }^{10}$

\subsection{Mediação e conciliação}

O artigo 694 do novo do Código de Processo Civil traz a confluência de esforços para uma solução consensual da controvérsia, ao incluir os institutos da mediação e conciliação.

Art. 694. Nas ações de família, todos os esforções serão empreendidos para a solução consensual da contro- vérsia, devendo o juiz dispor do auxílio de profissionais de outras área de conhecimento para a mediação e conciliação.

Parágrafo único. A requerimento das partes, o juiz pode determinar a suspensão do processo enquanto os litigantes se submetem à mediação extrajudicial ou a atendimento multidisciplinar.

O artigo 694 do novo CPC evidencia, quando afirma que todos os esforços serão envidados para a solução consensual do conflito, dispondo o juiz de auxiliares nas áreas de mediação e conciliação. Eis aqui a primeira grande modificação. O magistrado, na tentativa de uma solução amigável do embate, terá a contribuição de profissionais capacitados na utilização de técnicas de mediação ou conciliação.

Ao que parece, o legislador desejou que todos partícipes do processo sejam cooperadores para o término do conflito, criando "uma verdadeira integração entre o magistrado e as partes, para elaboração do mais adequado provimento jurisdicional à causa controvertida". ${ }^{11,12}$

10 MARINONI, Luiz Guilherme; ARENHART, Sérgio Cruz; MITIDIEIRO, Daniel. Novo código de processo civil comentado. São Paulo: Editora Revista dos Tribunais, 2015. p. 679.

11 TUPINAMBÀ, Carolina. Novas Tendências de participação processual - O amicus curiae no anteprojeto do novo CPC. In: FUX, Luiz (coord.). O novo processo civil brasileiro. Rio de Janeiro: Editora Forense, 2011. p. 111.

12 Cumpre esclarecer que a cooperação é entre o juiz com as partes, não entre as partes. Neste sentido a melhor doutrina: “[...] a colaboração no processo civil devida no Estado 
Constitui o cerne do artigo supracitado a promoção da autocomposição, com estímulo à mediação e à conciliação. Busca soluções pacíficas que digam respeito à tutela da família, com o que se evitaria sofrimentos desnecessários às partes, como disputas em que porventura sejam expostas questões da vida intima dos envolvidos, que não traz benefício a qualquer das partes litigantes. ${ }^{13}$

Assim, faremos uma abordagem dos novos institutos.

Como já afirmado alhures, uma das grandes novidades do novo Código de Processo Civil é a utilização de técnicas que propiciem a resolução de disputas, visando uma construção que indique a atenuação da relação conflitante.

Ora, os processos envolvendo questões familiares, não raras vezes, caracterizam-se pelo enfraquecimento ou rompimento da relação afetiva, em disputas que muitas vezes envol- vem menores. A rivalidade, a animosidade decorrem da ineficiência de todos atores processuais envolvidos.

O legislador inclui dentre estas técnicas a autocomposição como reflexo do amadurecimento de novos mecanismos na solvência de disputas.

O fato de atravessarmos uma época marcada pela complexidade, pela interdependência, pela velocidade das mudanças e das comunicações se faz refletir no quadro da resolução de conflitos. É necessário construir métodos que deem conta de novos desafios de uma economia globalizada e de uma sociedade cada vez mais consciente de seus direitos e cada vez mais sedenta de canais que viabilizem a resolução célere e pacífica de seus interesses. ${ }^{14}$

O novo Código de Processo Civil inova, na medida em que insere como auxiliares da justiça o conciliador judicial e o mediador ${ }^{15}$, uma vez que não existiam figuras correlatas no código de 1973.

Constitucional não é uma colaboração entre as partes. É uma colaboração do juiz para com as partes. Pode ocorrer de uma das partes ter de cooperar com o juízo a fim de que este colabore com a outra. Isto de modo nenhum autoriza, contudo, que se diga que há colaboração entre as partes. (MARINONI, Luiz Guilherme; MITIDIEIRO, Daniel. $O$ projeto do novo CPC: críticas e proposições. São Paulo: Editora Revista dos Tribunais, 2010. p. 73.)

13 WAMBIER. Teresa Arruda Alvim (coord.). Breves comentários ao novo código de processo civil. São Paulo: Editora Revista dos Tribunais, 2015. p. 1.601.

14 SOUZA, Luciana Moessa. Mediação: acesso à justiça e desenvolvimento institucional. In: CASELLA, Paulo Borba; SOUZA Luciane Moessa de (coords.). Mediação de conflitos: novo paradigma de acesso à justiça. Belo Horizonte: Editora Fórum, 2009. p. 69.

15 Art. 149. São auxiliares da Justiça, além de outros cujas atribuições sejam determinadas pelas normas de organização judiciária, o escrivão, o chefe de secretaria, o oficial 
Importa consignar chamar a atenção quanto à diferenciação dos dois institutos - Conciliação e Mediação.

Entende-se por conciliação a importante técnica voltada à solução de conflitos para a pacificação social. Auxiliando na tomada de decisão pelo conciliador, mediante concessões mútuas, os interessados estabelecem entre si a solução que melhor atenda as suas necessidades e os seus interesses, sem que haja total renúncia ou submissão de uma parte à outra. ${ }^{16}$

Por sua vez, a mediação é um método não adversarial, consensual e informal, pelo qual uma terceira pessoa imparcial - escolhida ou aceita pelas partes - auxilia os interessados a buscar uma solução justa e adequada ao caso submetido à apreciação. Atuando de modo a facilitar a compreensão do problema, mas sem interferir diretamente, a mediação en- coraja e facilita a resolução de uma divergência. ${ }^{17}$

É uma forma de resolução de controvérsia que trabalha com a ideia de conflito positivo e se baseia na forma de conduzir o problema a uma solução, que atenda às necessidades e aos interesses das partes. ${ }^{18}$

O principal objetivo da mediação é a satisfação das partes. Atingi-la significa a identificação da melhor solução para o conflito na interpretação delas, e a consequente celebração do acordo, atendendo a essa solução. ${ }^{19}$

Uma relevante influência dos institutos será quando houver disputas abrangendo menores, dado que deve viger o princípio do melhor interesse da criança. Amiúde os magistrados não tinham instrumentos técnicos para uma decisão que poderia incorrer em error in iudicando.

Neste sentido, o autor Ádamo Brasil Dias:

de justiça, o perito, o depositário, o administrador, o intérprete, o tradutor, o mediador, o conciliador judicial, o partidor, o distribuidor, o contabilista e o regulador de avarias. 16 FARINELLI, Alisson; CAMBI, Eduardo. Conciliação e mediação no novo Código de Processo Civil. In: Revista de Processo, ano 36, v. 194, abril/2011, Editora Revista dos Tribunais, p. 286.

17 FARINELLI, Cambi. Op. cit., p. 288.

18 SOUZA, Monaliza Costa de. A mediação como instrumento de pacificação e diálogo para as famílias. In: NORONHA, Carlos Silveira (org.). As novas posturas jurídicas em prol da família a partir da codificação civil de 2002. Porto Alegre: Editora Sulina, 2013. p. 288.

19 JUNIOR. Marcos Julio Olibé Melhadas. Psicologia na mediação: inovando a gestão de conflitos interpessoais e organizacionais. São Paulo: Editora LTR, 2004. p. 53. 
Quando o superior interesse da criança precisa ser identificado em um contexto de disputa entre os genitores, o trabalho do juízo é ainda mais árduo, visto que não raras vezes revestese de incerteza a escolha da opção que melhor atende aos interesses da criança em desenvolvimento. ${ }^{20}$

Pensamos que no âmbito familiar a mediação constitui o meio mais adequado de autocomposição, já que as técnicas se coadunam mais com os litígios de família, e que vai ao encontro do espírito do art. 165 , $\S 3^{\circ}$ da nova legislação. ${ }^{21}$

De dizer que recentemente foi aprovado no Senado Federal o Projeto de Lei (PLS 517, de 2011) que regulamenta a mediação judicial e extrajudicial como forma de solução de conflitos, carecendo agora apenas da sanção presidencial.

Conclui o parágrafo do art. 694 do novo Código de Processo Civil que, a requerimento das partes, o juiz pode determinar a suspensão do pro- cesso enquanto os litigantes se submetem à mediação extrajudicial ou a atendimento multidisciplinar. Há, assim, uma tentativa de substituir a cultura da guerra, pela cultura da paz, o que demandará não só uma mudança de atitude dos profissionais da área como também uma alteração no modo de ensino da ciência processual nas Faculdades de Direito do Brasil. A ideia do superadvogado, sempre vencedor, deverá ser substituída por um bom mediador ou por um conciliador de conflitos. ${ }^{22}$

\subsection{Da petição inicial e citação}

O artigo 695 aduz:

Art. 695. Recebida a petição inicial e, se for o caso, tomadas as providências referentes à tutela provisória, o juiz ordenará a citação do réu para comparecer à audiência de mediação e conciliação, observado o disposto no art. 694.

20 BRASIL. Ádamo Dias. A proteção dos filhos na dissolução da sociedade conjugal. In: NORONHA, Carlos Silveira (org.). As novas posturas jurídicas em prol da família a partir da codificação civil de 2002. Porto Alegre: Editora Sulina, 2013. p. 60.

21 Art. 165. Os tribunais criarão centros judiciários de solução consensual de conflitos, responsáveis pela realização de sessões e audiências de conciliação e mediação e pelo desenvolvimento de programas destinados a auxiliar, orientar e estimular a autocomposição. [...] § $3^{\circ} \mathrm{O}$ mediador, que atuará preferencialmente nos casos em que houver vínculo anterior entre as partes, auxiliará os interessados a compreender as questões e os interesses em conflito, de modo que eles possam, pelo restabelecimento da comunicação, identificar, por si próprios, soluções consensuais que gerem benefícios mútuos.

22 TARTUCE, Flávio. O novo CPC e o direito civil. Rio de Janeiro: Editora Método, 2015. p. 342. 
§ $1^{\circ} \mathrm{O}$ mandado de citação conterá apenas os dados necessários à audiência e deverá estar desacompanhado de cópia da petição inicial, assegurado ao réu o direito de examinar seu conteúdo a qualquer tempo.

$\S 2^{\circ}$ A citação ocorrerá com antecedência mínima de 15 (quinze) dias da data designada para a audiência.

§ 3o A citação será feita na pessoa do réu.

$\S 44^{\circ} \mathrm{Na}$ audiência, as partes deverão estar acompanhadas de seus advogados ou de defensores públicos.

Logo que recebida a petição inicial, se for o caso, o juiz resolverá as medidas acautelatórias e, de inopino, marca a audiência de mediação e conciliação, que, a partir de agora, é obrigatória.

Merece algumas reflexões e questionamentos relacionados à audiência. Será que, embora impositiva, o não comparecimento do réu à audiência acarretará que o mesmo seja conduzi- do a juízo debaixo de vara? Será que se presume o comportamento errático do réu?

Como já manifestamos, as ações de família possuem alto grau de tensionamento e, por vezes, a ruptura causou tantos dissabores e mágoas entre os consortes que os mesmos não querem mais ter contato algum. Por isso, pensamos que a obrigatoriedade ao comparecimento à audiência ofende a esfera da autonomia da vontade ${ }^{23}$, já que a Legislação Adjetiva vaticina sanção aquele que, embora intimado, não comparece ao ato processual.

Ademais, a norma não prediz a punição daquele que conscientemente não comparece à audiência. Perscrutando uma interpretação sistemática e teleológica, ponderamos que poderão ser utilizadas as regras do procedimento comum ordinário, previstas no art. 334, parágrafo $8^{\circ}$ do novo Código

23 Autonomia da vontade, na conceituação do professor Francisco dos Santos Amaral Neto: "Vontade, para o direito, reveste-se de especial importância pela circunstância de constituir-se um dos principais elementos do ato jurídico. Manifestando-se de acordo com os preceitos legais, a vontade produz determinados efeitos, criando, modificando ou extinguindo relações jurídicas, caracterizando, assim, a vontade jurídica. [...] A liberdade jurídica é, portanto, a possibilidade de a pessoa atuar com transcendência jurídica. Se encarada do ponto de vista do sujeito, realiza-se no poder de criar, modificar ou extinguir relações jurídicas; se encarada objetivamente, é o poder de regular juridicamente tais relações, dando-lhes conteúdo e eficácia determinada, reconhecida e protegida pelo direito". AMARAL NETO, Francisco dos Santos. A autonomia privada como princípio fundamental da ordem jurídica: perspectivas estrutural e funcional. Revista de Informações Legislativas, v. 26, n. 102, Brasília, abril/junho 1989, p. 212. Disponível em: <http://www2.senado.leg.br/bdsf/handle/id/22/browse?value=Amaral +Neto\%2C+Francisco+dos+Santos\&type=author $>$. Acesso em: 19 jun. 2015. 
de Processo Civil ${ }^{24}$, a saber, que será considerado ato atentatório à dignidade da justiça.

De dizer que se o juiz determinar a condução coercitiva do réu "discrepa, a mais não poder, de garantias constitucionais implícitas e explícitas (a preservação da dignidade humana, da intimidade, da intangibilidade do corpo humano, do império da lei e da inexecução específica e direta de obrigação de fazer) do provimento judicial” ${ }^{25}$ que obrigue a umas das partes comparecer à audiência.

Entendemos que a mediação é instrumento imprescindível para administração pacífica do conflito, contudo, compreendemos que a compulsoriedade no comparecimento da audiência é medida déspota, não havendo consentâneo com nossa Carta Magna.
Insta salientar que o mandado de citação conterá apenas os dados necessários para a audiência, não devendo ser acompanhado de cópia da petição inicial. Significa que o réu, nas ações de família, deve ser citado sem receber a cópia da petição inicial. Será apenas informado que há uma audiência na qual deve comparecer.

Neste sentido Leonardo Carneiro Cunha:

O objetivo é estimular o acordo entre as partes, pois é muito comum que nas ações de família as petições contenham termos impróprios, acusações exageradas, arroubos de impulsividade, que só servem para acirrar os ânimos e dificultar a autocomposição. ${ }^{26}$

Podemos redarguir se o recebimento do mandado, sem a contrafé,

24 Art. 334. Se a petição inicial preencher os requisitos essenciais e não for o caso de improcedência liminar do pedido, o juiz designará audiência de conciliação ou de mediação com antecedência mínima de 30 (trinta) dias, devendo ser citado o réu com pelo menos 20 (vinte) dias de antecedência. [...] $\S 8^{\circ} \mathrm{O}$ não comparecimento injustificado do autor ou do réu à audiência de conciliação é considerado ato atentatório à dignidade da justiça e será sancionado com multa de até dois por cento da vantagem econômica pretendida ou do valor da causa, revertida em favor da União ou do Estado.

25 BRASIL. Supremo Tribunal Federal, Tribunal Pleno. Habeas Corpus n. 71373. Relator: Ministro Francisco Rezek. 10 jun. 1996. <http://www.stf.jus.br>. Acesso em: 4 jun. 2015.

26 CUNHA, Leonardo Carneiro. Procedimento especial para as ações de família no projeto do novo código de processo civil. In: FREIRE, Alexandre; DANTAS, Bruno; NUNES, Dierle; DIDIER JR., Fredie; MEDINA, José; FUX, Luiz; VOLPE, Luiz; MIRANDA; Pedro (orgs.). Novas tendências do processo civil. Salvador: Editora JusPODIVM, 2013. p. 35. 
incluindo somente os dados da audiência, não iria suscitar um espírito exponencialmente belicoso à parte que recebe, pois sequer saberá os fundamentos da petição. Embora se possa ter vista dos autos a qualquer tempo, poderá ocorrer do réu chegar à audiência e não saber os motivos ensejadores do processo.

Flavio Tartuce, inclusive, provoca dizendo que resta vilipendiado o direito à informação, consequência da boa-fé objetiva:

[...] parece existir uma contrariedade ao dever de informação, corolário da boa-fé objetiva, que é um dos princípios no Novo CPC. Como fazer um acordo sem ter o mínimo do que está sendo pleiteado? [...]. ${ }^{27}$

Ainda, há quem advogue a inconstitucionalidade do dispositivo, visto que fere o princípio do contraditório:

Tal dispositivo, sobre o enfoque da garantia do contraditório, é manifestamente inconstitucional, pois inviabiliza o réu de saber, imediatamente, no momento da citação, os fatos e fundamentos jurídicos que a pretensão familiar contém. Mesmo que o artigo estabeleça a possibilidade de consulta dos autos a qualquer tempo pelo réu, isso não garante o contraditório, pois ele deve ser observado no exato momento da citação, e nunca em momento posterior, desnaturando o direito indisponível de publicidade que o instituto da citação reserva. ${ }^{28}$

\section{E continua:}

[...] verificamos a possibilidade de ocorrer o seguinte problema, qual seja, o réu recebe a citação, não sabe do que se trata, comparece na audiência de conciliação ou mediação e, somente nesse momento, vem a saber sobre eventuais fatos e fundamentos que estão sendo imputados como ilícitos, bem como descobre eventuais antecipações de tutela deferidas, alimentos provisórios, medidas protestivas e outras questões urgentes que não instruíram o mandado citatório e os impediram de ter conhecimento. $[\ldots]]^{29}$

Ponderamos à guisa da ideia do doutrinador, pois poderá ocorrer o atendimento de alguma medida assecuratória, que apanhará o réu de sobressalto, sem a oportunidade de impugnação em tempo hábil ou, somente após a audiência. É por óbvio,

27 TARTUCE, Flávio. O novo CPC e o direito civil. Rio de Janeiro: Editora Método, 2015. p. 342.

28 SOARES, Carlos Henrique. Ações de Direito de Família no Novo Código de Processo Civil Brasileiro. Revista síntese de direito de família, v. 15, n. 85, 2014, p. 18.

29 Ibidem, p. 19. 
tal conduta processual, prejudicial a sua defesa.

Caberá ao tempo responder se a medida foi profícua em diminuir a beligerância das partes nos processos que envolvem questões familiares ou serviu de motivação maior de contendas.

Ao depois, a citação será precedida minimamente 15 (quinze) dias antes da audiência. Dispõe, também, que a citação será pessoal.

As partes serão acompanhadas por seus procuradores ou acompanhadas por defensor público.

Poderá ocorrer que em comarcas que não dispõem de defensoria pública, o juiz designará um defensor dativo para acompanhar o réu na audiência, sob pena de não o fazendo padecer de vício nulificante.

Por sua vez, o art. 696 do codex aduz que a audiência de mediação e conciliação poderá ser dividida em tantas vezes quantas forem necessárias para o desenlace da solução consensual. Se, porventura, houver alguma providência a ser decidida enquanto não findar as sessões, a fim de não deixar perecer direitos, o juiz da causa a lhes deferirá.
A mediação e a conciliação podem ser processos longos. O legislador não ignorou este fato e previu essa possibilidade de divisão na quantidade de sessões necessárias. ${ }^{30}$

Ao permitir que a audiência de mediação e conciliação seja dividida em tantas sessões quantas necessárias para viabilizar a solução consensual sem prejuízo de providências jurisdicionais para evitar o perecimento do direito, o art. 696 do Novo CPC reforça mais uma vez a valoração das formas consensuais de conflito, permitindo que ela seja buscada em mais de uma sessão de audiência. ${ }^{31}$

É de bom alvitre que o juiz não seja partícipe das sessões de autocomposição, pois poderá ocorrer dos sujeitos do processo não chegarem a um acordo e, também, a fim de evitar que sua imparcialidade seja corrompida no momento de decidir. Isso ocorre porque as informações colhidas, por vezes, revelam a intimidade ou atos desabonatórios das partes, que só foram reveladas por meio de laboriosos esforços para a resolução do conflito, e não devem sopesar em eventual decisão.

30 WAMBIER, Teresa Arruda Alvim (coord.). Primeiros Comentários ao novo código de processo civil: artigo por artigo. São Paulo: Editora Revista dos Tribunais, 2015. p. 1.030 .

31 NEVES, Daniel Amorim Assumpção. Novo Código de Processo Civil: Lei 13.105/2015. São Paulo: Editora Método, 2015. p. 380. 
Nesta linha intelectiva, o enunciado 187 do Fórum Permanente de Processualistas Civis, veda qualquer tipo de ameaça ou constrangimento:

No emprego de esforços para a solução consensual do litígio familiar, são vedadas iniciativas de constrangimento ou intimidação para que as partes conciliem, assim como as de aconselhamento sobre o objeto da causa." 32

Como visto, o novo Código de Processo Civil priorizou a resolução dos conflitos familiares da forma a diminuir o desgaste emocional, o qual decorre da complexa relação parental, buscando sempre uma composição amigável.

Por sua vez, o artigo 697 do novo Código de Processo Civil diz que embora toda eiva de esforços, se houver frustração na construção dos pilares da pacificação, será seguida a marcha do procedimento comum, sendo o réu intimado para apresentação de contestação ao receber a cópia da petição inicial.

\subsection{Intervenção do Ministério Público}

Uma aprazível surpresa que a novel legislação contém é a participação do Ministério Público, que nas ações de família somente intervirá quando houver interesse de incapaz, consoante reza o artigo 698 do novo Código de Processo Civil.

A previsão deste artigo nos remete ao papel constitucional deste ministério, que deve se ater às questões públicas e de interesse público. Assim, nem todas as ações de família dizem respeito ao Ministério Públi$\mathrm{CO}^{33}$, portanto, a modificação veio em boa hora.

Aliás, proposição defendida por Rolf Madaleno, ao tecer alguns comentários sobre a dissolução do casamento:

\begin{abstract}
Em determinadas circunstâncias não há mais de ser falado em direitos indisponíveis, conquanto não envolva interesses dos filhos menores e incapazes do casal e, tampouco, haverá de participar o Ministério Público como
\end{abstract}

32 Disponível em: <http://www.academia.edu/9845423/Enunciados_consolidados_ do_F\%C3\%B3rum_Permanente_de_Processualistas_Civis>. Acesso em: 2 jun. 2015. 33 VILLAS-BÔAS, Renata Malta. O direito das famílias no âmbito dlo Novo Código de Processo Civil: PL 8.046/2010. In: Revista Síntese Direito de Família, v. 15, n. 85, agosto/setembro 2014, p. 29. 
fiscal da lei, na defesa de interesses já disponibilizados pela lei. ${ }^{34}$

Assim, somente interferir o membro do parquet, quando houver interesse de incapazes.

\subsection{Dos casos de abuso e alienação parental}

Por fim, o artigo 699 do novo Código de Processo Civil dispõe que "se o caso envolver discussão sobre fato relacionado a abuso ou alienação parental”35, ao tomar o depoimento de incapaz o juiz deve se cercar de uma equipe multidisciplinar para tratar do tema, eis que a criança deve ser muito fragilizada.

A alienação parental, um conceito muito melhor formulado, foi apresentado em 1985, por meio da divulgação de um artigo do professor especialis- ta e perito judicial doutor Richard Gardner, que, interessado no comportamento das crianças durante os processos de divórcios litigiosos, observando os hábitos e atitudes dessas, identificou o fenômeno denominado Alienação Parental. ${ }^{36}$

O abuso pode ser psicológico, sexual e de qualquer outra natureza. Qualquer tipo de abuso gera fragilidade. ${ }^{37}$

Assim, é de bom alvitre a participação do plexo social a amparar o Poder Judiciário, minorando os efeitos devastadores do abuso e da alienação parental.

\section{CONSIDERAÇÕES FINAIS}

O advento de um novo Código de Processo Civil é uma realidade. Vislumbram-se os esforços para um

34 MADALENO, Rolf. Curso de Direito de Família. 1. ed. Rio de Janeiro: Editora Forense, 2008. p. 265.

35 Um conceito de alienação parental, pode ser encontrado no art. $2^{\circ}$ da Lei 12.318 de 26 de agosto de 2010: “Considera-se ato de alienação parental a interferência na formação psicológica da criança ou do adolescente promovida ou induzida por um dos genitores, pelos avós ou pelos que tenham a criança ou adolescente sob a sua autoridade, guarda ou vigilância para que repudie genitor ou que cause prejuízo ao estabelecimento ou à manutenção de vínculos com este”.

36 FREITAS. Douglas Philips. Alienação Parental: Comentários à Lei 12.318/2010. Rio de Janeiro: Editora Forense, 2014. p. 22.

37 WAMBIER, Teresa Arruda Alvim (coord.). Primeiros comentários ao novo código de processo civil: artigo por artigo. 1. ed. São Paulo: Editora Revista do dos Tribunais, 2015. p.1.032. 
novo modelo de processo e louvam-se as intenções da atividade legiferante. Depreende-se da Lei Adjetiva uma valorização da dimensão social ao transformar o processo em instrumento da busca da pacificação social.

A presente reflexão pretendeu dar destaque a alguns aspectos relacionados à indelével mudança que ocorreu no processo que trata das questões familiares.

Por uma questão de predileção, optamos em tecer algumas considerações sobre os processos litigiosos de família, visto que é uma das grandes novidades do novo Código de Processo Civil.

Por primeiro, fizemos algumas considerações sobre as transformações que experimentou o processo contencioso de família, havendo um procedimento próprio, com suas idiossincrasias e especificidades.

As aplicações das normas esposadas neste trabalho somente vigeram nos casos de divórcio, separação, reconhecimento e extinção de união estável. Ponderemos se somente nestes casos o procedimento poderá ser adotado, ou em outras ações de direito de família. Será que é apenas um rol exemplificativo, ou taxativo? Nossa posição neste momento é a de afirmar que o alcance da norma somente consistirá nos casos previstos na Lei.

Ao depois, abordamos uma das proeminentes inovações que o novo Código de Processo Civil nos brindou, que é a tentativa da solução do conflito de forma amigável. Foram inse- ridos na ordem jurídica dois institutos de autocomposição valorosos, quais sejam: a conciliação e a mediação.

Considerou o novo Código de Processo Civil que os conflitos e as situações litigiosas podem e devem ser solucionados por aqueles envolvidos nas disputas, utilizando-se de mecanismos para resolver a controvérsia.

Consideramos que a melhor via eleita para deslindar as questões de família será a mediação, porquanto é uma técnica normativa-resolutiva de conflitos.

O ímpeto de resultado foi tal que o magistrado, inclusive, pode suspender o processo a fim de que as partes se submetam à mediação ou ao atendimento multidisplinar e, também, pode dividir as sessões de mediação e conciliação em quantas vezes forem necessárias para o deslinde do litígio.

Doravante, recebida a petição inicial e resolvidas as questões de tutela provisória, imediatamente será marcada, obrigatoriamente, audiência de mediação ou conciliação.

Indagamos se o não comparecimento do réu na audiência suscitaria alguma penalidade. Replicamos que a obrigatoriedade do comparecimento é medida desarrazoada, uma vez que o próprio sistema processual prevê algum tipo de sanção.

De lembrar que o mandado judicial somente conterá dados necessários à audiência, sem o acompanhamento da exordial. Ponderamos até 
que ponto é salutar o réu comparecer a um ato judicial sem ter informações mínimas quanto à questão controvertida. Pode ocorrer de haver o processo "surpresa”, já que não pode tomar ciência dos fatos narrados na petição de origem. Questionamos se tal medida, em vez de trazer benefícios, trará um espírito combativo à demanda.

Contudo, se todos os esforços para a solução consensual restarem inexitosos, incidirão as regras do procedimento comum.

Outra agradável surpresa é o papel do Ministério Público, que somente intervirá em causas que envolverem incapazes. Assim, nem todas as causas terão a participação do órgão ministerial.

\section{REFERÊNCIAS}

AMARAL NETO. Francisco dos Santos. A autonomia privada como princípio fundamental da ordem jurídica: perspectivas estrutural e funcional. Revista de Informações Legislativas, v. 26, n. 102, Brasília, abril/ junho 1989.

BRASIL. Constituição da República Federativa do Brasil de 1988.

BRASIL. Lei n. 13.105, de 16 de março de 2015.

BRASIL. Lei n. 5.869, de 11 de janeiro de 1973.
E, por fim, o novo Código de Processo Civil atentou para aqueles casos em que houver abuso ou alienação parental, instituindo a participação de equipe multidisciplinar quando houver o depoimento do incapaz.

É evidente que foram traçadas apenas algumas considerações que não esgotam neste ensaio. Com o passar do tempo, tanto nossos laboriosos doutrinadores quanto as circunspectas decisões judiciais não irão se imiscuir em empreender esforços para responder questões debatidas aqui, e ainda as que virão a serem debatidas.

A maturação da disciplina processual é medida que, com o passar dos dias, irá dar uma reposta efetiva as nossas indagações, ou não.

BRASIL. Supremo Tribunal Federal, Tribunal Pleno. Habeas Corpus n. 71.373. Relator: Ministro Francisco Rezek. 10 jun. 1996. <http://www. stf.jus.br>. Acesso em: 4 jun. 2015. CINTRA, Antonio Carlos de Araújo; GRINOVER, Ada Pellegrini; DINAMARCO, Cândido Rangel. Teoria geral do processo. 29. ed. São Paulo: Editora Malheiros, 2013.

CUNHA, Leonardo Carneiro. Procedimento especial para as ações 
de família no projeto do Novo Código de Processo Civil. In: FREIRE, Alexandre; DANTAS, Bruno; NUNES, Dierle; DIDIER JR., Dierle; GARCIA MEDINA, José Miguel; FUX, Luiz; VOLPE CAMARGO, Luiz Henrique; OLIVEIRA, Pedro Miranda de (orgs.). Novas tendências do processo civil. Salvador: Editora Juspodivm, 2013.

DIAS, Ádamo Brasil. A proteção dos filhos na dissolução da sociedade conjugal. In: NORONHA, Carlos Silveira (org.). As novas posturas jurídicas em prol da família a partir da codificação civil de 2002. Porto Alegre: Editora Sulina, 2013.

FARINELLI, Alisson; CAMBI, Eduardo. Conciliação e mediação no novo Código de Processo Civil. In: Revista de Processo, ano 36, v. 194, abr. 2011, Editora Revista dos Tribunais.

FREITAS, Douglas Philips. Alienação Parental: Comentários à Lei 12.318/2010. Rio de Janeiro: Editora Forense, 2014.

JUNIOR, Marcos Julio Olibé Melhadas. Psicologia na mediação: inovando a gestão de conflitos interpessoais e organizacionais. São Paulo: Editora LTR, 2004.

LUCENA, João Paulo; DA SILVA, Ovídio A. Baptista. Comentários ao código de processo civil: dos procedimentos especiais, arts.
1.103 a 1.210. São Paulo: Editora Revista dos Tribunais, 2000.

LÔBO, Paulo. Luz e sombra. Revista do Instituto Brasileiro de Família, 19. ed., fev./mar. 2015.

MADALENO, Rolf. Curso de Direito de Família. 1. ed. Rio de Janeiro: Editora Forense, 2008.

MARCATO. Antônio Carlos. Procedimentos Especiais. 14. ed. São Paulo: Editora Atlas, 2010.

MARINONI, Luiz Guilherme; ARENHART, Sérgio Cruz; MITIDIEIRO, Daniel. Novo código de processo civil comentado. São Paulo: Editora Revista dos Tribunais, 2015.

MARINONI, Luiz Guilherme; MITIDIEIRO, Daniel. O projeto do novo CPC: críticas e proposições. São Paulo: Editora Revista dos Tribunais, 2010.

NEVES. Daniel Amorim Assumpção. Novo Código de Processo Civil: Lei 13.105/2015. São Paulo: Editora Método, 2015.

NORONHA, Carlos Silveira. A função social do Direito de Família na tutela dos entes familiares. In: NORONHA, Carlos Silveira (org.). As novas posturas jurídicas em prol da família a partir da codificação civil de 2002. Porto Alegre: Editora Sulina, 2013.

SILVA, Regina Beatriz Tavares da. Divórcio e separação após a EC n. 66/2010. 2. ed. São Paulo: Editora Saraiva, 2012. 
SOARES, Carlos Henrique. Ações de Direito de Família no Novo Código de Processo Civil Brasileiro. Revista síntese de direito de família, v. 15, n. 85, 2014.

SOUZA, Luciana Moessa. Mediação: acesso à justiça e desenvolvimento institucional. In: CASELLA, Paulo Borba; SOUZA, Luciane Moessa de. (Coords.) Mediação de conflitos: novo paradigma de acesso à justiça. Belo Horizonte: Editora Fórum, 2009.

SOUZA, Monaliza Costa de. A mediação como instrumento de pacificação e diálogo para as famílias. In: NORONHA, Carlos Silveira (org.). As novas posturas jurídicas em prol da família a partir da codificação civil de 2002. Porto Alegre: Editora Sulina, 2013.

TARTUCE, Fernanda. Possibilidade de diversas sessões consensuais no juízo familiar. Revista do Instituto Brasileiro de Direito de Família, 19. ed., fev./mar. 2015.
TARTUCE, Flávio. O novo CPC e $o$ direito civil. Rio de Janeiro: Editora Método, 2015.

TUPINAMBÁ, Carolina. Novas Tendências de participação processual: o amicus curiae no anteprojeto do novo CPC. In: FUX, Luiz (coord.). O novo processo civil brasileiro. Rio de Janeiro: Editora Forense, 2011.

VILLAS-BÔAS, Renata Malta. O direito das famílias no âmbito do Novo Código de Processo Civil - PL 8.046/2010. In: Revista Síntese Direito de Família, v. 19, n. 85, ago./set. 2014.

WAMBIER, Teresa Arruda Alvim (coord.) Breves comentários ao novo código de processo civil. São Paulo: Editora Revista dos Tribunais, 2015.

- Primeiros Comentários ao novo código de processo civil: artigo por artigo. São Paulo: Editora Revista dos Tribunais, 2015. 